\title{
Surveying and Documenting of the Cultivated Plants and Evaluation of Air Pollution in Historical Gardens in Alexandria, Egypt (A) Shallalat Garden
}

\author{
Nader A. El-Shanhorey ${ }^{1}$
}

\begin{abstract}
Alexandria is one of the largest cities in Egypt in terms of population and urban density, second only to Cairo. Since its origination in the 300s BC, it has been one of the biggest metropolises in the ancient world, culturally, intellectually, politically and economically. Alexandria's classy urban environment over the different eras was always reflected in the creation of gardens and public spaces for its inhabitants since the Ptolemaic era.

The loss of area in Shallalat garden is substantially large, rising up to $56 \%$. This trend represents a serious threat to the other gardens that might be facing the same aggressive urban erosion. On the other hand, the loss of area in the remaining Alexandria's gardens is existent but not threatening. The major losses in areas were in Shallalat garden. However, it is worth mentioning that this loss in area to urbanism didn't affect the quality of the remaining area of the gardens. This paper aims to present a descriptive profile of the historical gardens in Alexandria, from their initial design to their current state today.

The garden profiles are gathered in the form of two sets. The first one consists of the archaeological installations including historical background, and a snapshot of the important elements that define this park. The second set consists of the plant surveying cultivated in the garden. The garden contains many plant groups such as trees, shrubs, climbers, palms and succulent. These groups belong to 33 families, 59 genera and 79 species. The plant groups planted in the Shallalat garden are of high value due to the high age and the few numbers in the Alexandria city. The garden contains some plant groups, but it lacks a lot of plants to complete the groups in the garden and to restore the beauty and splendor of the historic garden. In addition to as the garden is located in the center of Alexandria, which means that it is located in a high-density traffic area, and therefore the Air Pollution Tolerance Index (APTI) was calculated for different plants cultivated in the garden.
\end{abstract}

Key Word: Shallalat garden- Archaeological installations - Cultivated groups plants - Air Pollution Tolerance Index (APTI).

\section{INTRODUCTION}

Being the second biggest city in Egypt, second to Cairo, Alexandria has proven to be as important as the Egyptian capital itself over time. According to the UN report for State of the World's Cities in 2013, the city population growth rate of urban agglomerations for Alexandria has always been higher than that for Cairo since 1990 all the way through to the expected growth rate in 2025 for both cities (Abdou Aziz, 2004). It's also worth mentioning that it actually was the Egyptian capital starting from the Ptolemaic Era (Bell, 1927) in 331 BC till Arabs conquered Egypt in 641 AD. After its origination in the $300 \mathrm{~s} \mathrm{BC}$, it has become, in no time, the biggest metropolis in the ancient world, culturally, intellectually, politically and economically. Regarding cultural backgrounds, Alexandria is considered to be the most multi-cultural and extremely diverse city in Egypt. This is related to the Mediterranean as well as global integration and exposure that made Alexandria an approachable and inhabitable city for different nationalities and ethnicities. This also reflects on the names of the Alexandrian districts, Greek names such as "Bacus" (Bacchus), Ptolemaic names such as "Soter", Roman/Coptic names such as "San Stefano", Arab names like "Shatby", Jewish names such as "Semouha", modern European names like "Stanley", and modern Egyptian names like "Moustafa Kamel" (Saad El-Din et al., 1993).

Since its foundation in the Ptolemaic period, Alexandria has always exhibited a classy urban environment throughout the variously rich eras that have come over the city. The high quality of the urban environment in Alexandria was emphasized by creating gardens and public spaces for the community since the Ptolemaic era (300 BC). "There were many gardens; for the Alexandrians shared the Egyptian love for flowers, and the flower-sellers and sellers of garlands were a familiar sight in the streets" (Bell, 1927). An example of the ancient gardens in Alexandria since the Ptolemaic era is El-Nozha, Antoniadis, Rose and Alex Zoo Gardens Complex. This complex comprises a group of gardens located east of Alexandria city along the Mahmoudiyah Canal, and still standing till our present day, making it one of the most ancient gardens in Egypt and the Middle East (Ilbert, 1996; Hamdy, 2010).

DOI: 10.21608/asejaiqjsae.2021.193586

Botanical Gardens Research Department, Horticulture Research Institute,

Agricultural Research Center, Alexandria, Egypt (dr_shanhorey@yahoo.com)

Received August 05, 2021, Accepted, September 08, 2021. 
In a historical city like Alexandria, layers of history are illustrated in its gardens. Left unearthed and neglected, these vital spaces are subject to negative change and decay under the pressure of land use demands, among various other challenges. Many of Alexandria's gardens date back to the $19^{\text {th }}$ and $20^{\text {th }}$ century, containing endless gestures from the cultural essence of this time era in their design (Abd El-Aziz, 2012).

Frederick Law Olmsted (April 26, 1822 - August 28, 1903) was an American journalist, social critic, public administrator, and landscape designer. $\mathrm{He}$ is popularly considered to be the father of American landscape architecture, although many scholars have bestowed that title upon Andrew Jackson Downing. Olmsted was famous for co-designing many wellknown urban parks with his senior partner Calvert Vaux, including Central Park and Prospect Park in New York City (Beveridge and Rocheleau, 1998). Olmstead also participated in many landscape works in addition to many countries in the world, including Egypt, where he designed the Shallalat garden in Alexandria (Abd ElRahman, 2017). Olmsted was hired by the Baptist Church to develop a residential community that blended in seamlessly with the natural world around it.

The aim of this study is the historical description of the garden, in addition to document the cultivated plants, as well as dividing the content of the garden on a botanical group represented by (79) species belonging to (59) genera and (33) families. As the garden is located in the center of Alexandria, which means that it is located in a high-density traffic area, therefore the Air Pollution Tolerance Index (APTI) was calculated for different plants grown in the garden.

\section{MATERIALS AND METHODS}

\section{History and Location}

The Shallalat Garden is located in the Shatby area ( $\left.31^{\circ} 21^{\prime} 11^{\prime \prime} \mathrm{N} \& 29^{\circ} 54^{\prime} 50^{\prime \prime} \mathrm{E}\right)$ in the site of the Royal Palace gardens and old Alexandria Library of the Graeco-Roman era, and it is considered as the third largest public park in Alexandria. It was laid out following the ideas of the American landscaper Frederick Law Olmsted, and include towers that were once a part of the Ancient Roman Alexandria wall and Copper Fortress, 'Tabia El-Nahassen', where copper tools were manufactured in the era of Mohammed Ali (Hamdy, 2010). In 1958, the total area of the gardens was 68 Feddans, but by 1984, after the establishment on the site of the Olympic Club (9.5 Feddans) and the Waterfalls Youth Centre (2.7 Feddans), road expansion, and the construction of a natural gas pipe storage area, its extant was reduced to 41.5 Feddans. In 1999, the expansion of the Suez Canal Road and the construction of Abdel-Moneim Riad Tunnel, a child library, the house for the Supreme Council of Antiquities and a police station, it was further decreased to 34 Feddans. Today, the total area of the Northern and Southern parts are less than 28.5 Feddans (20 feddans Northern Shallalat and 8.5 feddans Southern Shallalat). The development of Shallalat historical relics along time is mapped. The northern garden is characterized by its natural style consisting of elevations and depressions, an artificial pond and a large waterfall (Hamdy, 2010). The Shallalat Gardens are the only site with an archaeological area (remains of the old Alexandria fort) in the middle of the garden, Tabaih Al-Nahasin and Cistern Abn El-Nabih which is quite unique in terms of historical gardens in Egypt (Photo 1).

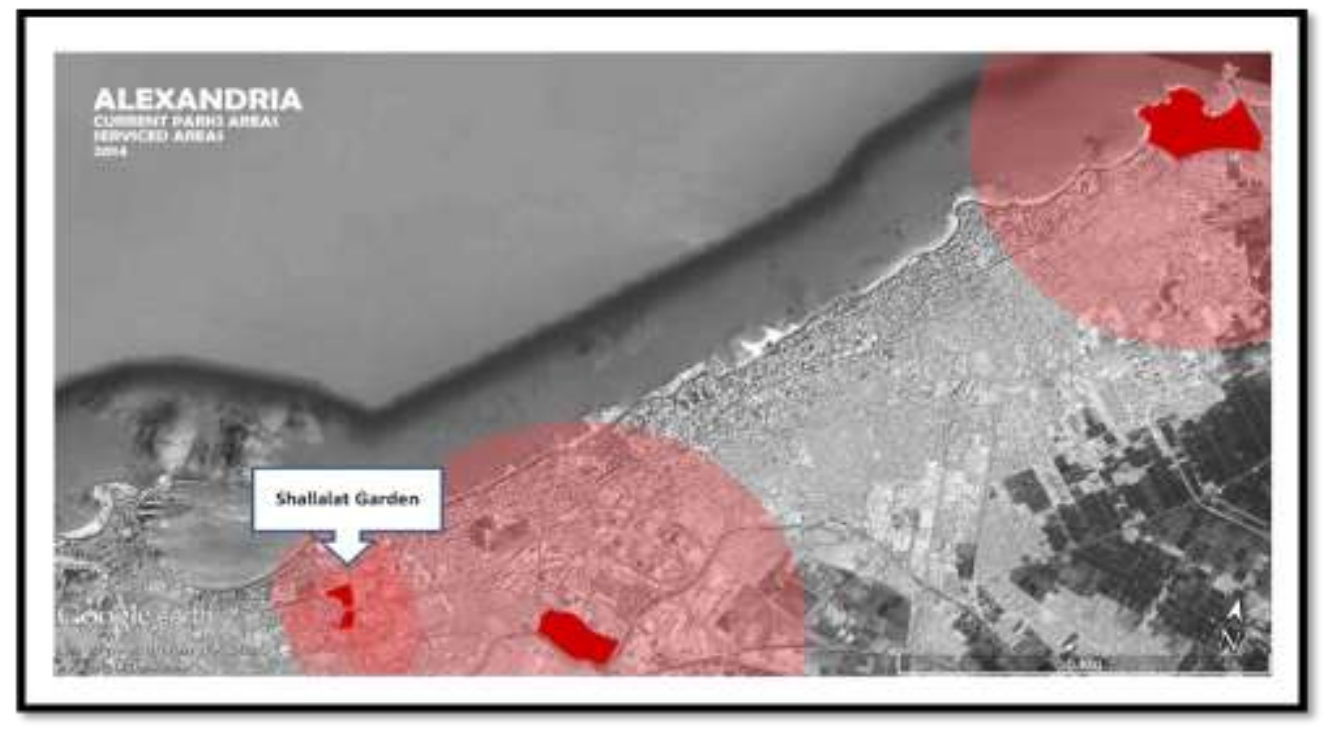

Photo 1. Map showing the location of Shallalat garden in Alexandria city. 


\section{Surveying and documenting of the cultivated plants}

Field trips were carried out to collect the studied species from Shallalat Garden in Alexandria, Egypt during the two successive seasons of 2019 and 2020. A total of (79) species represented (59) genera and (33) families were collected. The recorded genera were arranged alphabetically within their families (Table 1). Data collections for investigation and identification criteria of the studied taxa were based on the flora and taxonomic references (Bailey, 1947; Tackholm, 1974; Boulos, 1999, 2000, 2002 and 2005). The author collected about 76 specimens from the studied area. The plant collections were prepared as herbarium sheets.

Available information such as area, year of establishment, species composition and landmarks for the garden was obtained from several sources. Historical documents, photos, personal contact with authorities and researchers as well as travelers' books. Recent data including maps, photos and satellite images, for the gardens, have been downloaded using the Google Earth Software, It is hoped that the appended plant list of the floristic composition of Shallalat Garden is significant for any future studies in conserving national gardens (El-Torky et al., 2013).

\section{Air Pollution Tolerance Index (APTI)}

\section{Sampling}

Plants were randomly selected from the garden. Leaf samples of the various plants were then collected. Three replicates of fully matured leaves were taken and immediately taken to the laboratory for analysis. The plants selected for the present study were available at the site. After washing, the leaf fresh weight was taken immediately upon getting to the laboratory. Samples were preserved in refrigerator for other analyses.

\section{Relative Water Content of Leaves (RWC)}

Using the method described by Singh et al., (1997), leaf relative water content was determined and calculated with the formula.

$$
\begin{aligned}
& \mathbf{R W C}=(\mathbf{F W}-\mathbf{D W}) /(\mathbf{T W}-\mathbf{D W}) \times \mathbf{1 0 0} \\
& \text { FW }=\text { Fresh weight } \\
& \text { DW }=\text { Dry weight } \\
& \mathrm{TW}=\text { Turgid weight }
\end{aligned}
$$

Fresh weight was obtained by weighing the fresh leaves. The leaves were then immersed in water for $24 \mathrm{~h}$, blotted dry and then weighed to get the turgid weight. The leaves were than dried over-night in an oven at $70^{\circ} \mathrm{C}$ and reweighed to obtain the dry weight.

\section{Total Chlorophyll Content (TCh)}

According to the method of Moran (1982) as follows:

Half gram of fresh leaves were extracted by $10 \mathrm{ml}$. of N,N, Dimethyl formamide for 24-48 hours. In a dark place, temperature was kept at $4^{\circ} \mathrm{C}$ until all pigments were extracted. One ml. was taken from this mixture then completed with N,N, Dimethyl formamide to 10 $\mathrm{ml}$.

The absorbance of the extracts was measured at a wave length of $660 \mathrm{~nm}$. for chlorophyll A, $640 \mathrm{~nm}$. for chlorophyll B using spectrophotometer. The total chlorophyll content was calculated as $\mathrm{mg} / \mathrm{g}$ fresh weight. The equations for the determination of the concentrations of chlorophyll A, chlorophyll B and chlorophyll $\mathrm{A}+\mathrm{B}$ were:

$$
\begin{aligned}
& \text { Chlorophyll A }(\mathrm{ml} / \mathrm{L})=(9.784 * \text { E. } 660)-(0.99 * \\
& \text { E. 640) } \\
& \text { Chlorophyll B }(\mathrm{ml} / \mathrm{L})=(21.426 * \text { E. } 640)-(4.65 * \\
& \text { E. 660) } \\
& \text { Chlorophyll A+B }(\mathrm{ml} / \mathrm{L})=(5.134 * \text { E. } 660)+(20.436 * \\
& \text { E. 640) }
\end{aligned}
$$

\section{Leaf Extract pH}

$5 \mathrm{~g}$ of the fresh leaves was homogenized in $10 \mathrm{ml}$ deionised water. This was filtered and the $\mathrm{pH}$ of the leaf extract determined after calibrating $\mathrm{pH}$ meter with buffer solution of $\mathrm{pH} 4$ and 9.

\section{Ascorbic Acid (AA)}

Ascorbic acid content (expressed in $\mathrm{mg} / \mathrm{g}$ ) was measured using spectrophotometric method (Bajaj and Kaur, 1981). $1 \mathrm{~g}$ of the fresh foliage was put in a testtube, $4 \mathrm{ml}$ oxalic acid - EDTA extracting solution was added; then $1 \mathrm{ml}$ of orthophosphoric acid and then $1 \mathrm{ml}$ $5 \%$ tetra oxosulphate acid added to this mixture, $2 \mathrm{ml}$ of ammonium molybdate was added and then $3 \mathrm{ml}$ of water. The solution was then allowed to stand for 15 minutes. After which the absorbance at $760 \mathrm{~nm}$ was measured with a spectrophotometer. The concentration of ascorbic acid in the sample was then extrapolated from a standard ascorbic acid curve.

\section{Air Pollution Tolerance Index (APTI) Determination}

This was done following the method of Singh and Rao, (1983). The formula of APTI is given as:

\section{$\mathbf{A P T I}=\mathbf{A}(\mathbf{T}+\mathbf{P})+\mathbf{R} / \mathbf{1 0}$}

Where:

$\mathrm{A}=$ Ascorbic acid (mg/g dry wt.)

$\mathrm{T}=$ Total Chlorophyll (mg/g dry wt.)

$\mathrm{P}=\mathrm{pH}$ of leaf extract.

$\mathrm{R}=$ Relative water content of leaf tissue (\%). 
The Entire sum was divided by 10 to obtain a small manageable figure.

\section{Air Pollution Tolerance index range:}

$<1=$ Very Sensitive, 1 to $16=$ Sensitive, 17 to $29=$ Intermediate, 30 to $100=$ Tolerant (Kalyani and Singaracharya, 1995). This method expresses the capacity of a plant to battle against air pollution.

\section{Statistical analysis}

Statistical analysis of the studied species was based on excel program to calculate the following criteria: (1) The number and ratios of species per each family, (2) The number and ratios of genera per each family (climbers, palms, perennials, shrubs, succulents and trees).

The layout of the experiment was a randomized complete block design (RCBD) contained 35 treatments with three replicates. Data were subjected to analysis of variance (ANOVA) using the SAS program (SAS Institute, 2002). The Means of the individual factors and their interactions were compared by L.S.D test at 5\% level of probability according to Snedecor and Cochran (1989).

\section{RESULTS AND DISCUSSION}

The garden profiles are gathered in the form of two sets. The first one consists of the archaeological installations including historical background, and a snapshot of the important elements that define this park. The second set consists of the plant surveying cultivated in the garden. This garden was selected according to their historical significance for the Egyptian gardens as well as the availability of reliable data describing the nature of their landscape characteristics. In addition to calculating the air pollution tolerance index (APTI) for garden plants.

\section{Archaeological installations}

\subsection{Alexandria Wall}

The construction of the wall began during the reign of Great Alexander, but was not completed in its time, but was completed during the Ptolemaic era. The Romans fortified it. The wall surrounded the inhabited city in the shape of a rectangle, beginning west of the Canopus road, adjacent to the Mediterranean beach to "Rass Lokias" east, then descends south to the Alexandria canal, and then runs parallel to it until it reaches the point where it began (Al-Falaki, 1967 ; S. F.C., 1992).

The old wall was built of stones that were brought from the quarries of the Max area. The length of the outer wall of the city is $15.8 \mathrm{~km}$, with all its meandering and another 600 meters. It was the extension of the "Temunium", the residence of the Roman leader "Marc Antonius" in Alexandria, Although the ancient city as described by the Greek geographical "Astrabon" did not exceed $5.09 \mathrm{~km}$ tall, $1.15 \mathrm{~km}$ width on the west, 1.4 kilometers on the east and $1.7 \mathrm{~km}$ in the central part of the city(Al-Falaki, 1967). Today, more than 2300 years after the beginning of the construction of the wall of Alexandria, we can see the remains still standing in the eastern end of the garden of the southern waterfalls in front of the stadium, which is the only remaining part of the wall, but these remnants of the wall erected by "Ahmed Ben Tolon" In the third century (AH), an area of about 79.5 square meters. The wall had a great role in the protection of Alexandria throughout history. King Antiochus IV of Syria was unable to enter the wall and the city at the beginning of the $2^{\text {nd }}$ century $\mathrm{BC}$, The forces of the Roman emperor, "Diqaldionas", were unable to penetrate it for eight full months at the end of the third century (AD), and these walls continued to enjoy their strength until the Arab conquest (Al-Din Sameh, 1982 ; S. F.C., 1992).

Amro Ben Al-Aas was the first to demolish part of the Alexandria wall because of the occupation of the eastern Byzantine Empire in 645, and because he had to siege the Alexandria city a long time to be able to return it from the grip of the Byzantines, he thought to demolish part of the fence so as not to have a long siege If the city fell again into the hands of the invaders. In the reign of Ahmad Ben Tulun a new wall was built, surrounding the rest of the city, parts of the wall are still found in the Southern Shallalat garden (Photo 2), (Ibn Battuta, 1987; Ibn Jubayr, 2003).

In the Mamluk era, Sultan Beybars, in the year 676 $(\mathrm{AH})$, repaired 46 parts of wall and 17 towers of the northern front wall, which was cracked by an earthquake that hit Alexandria coast, the northern part of the fence is also supported by a front curtain overlooking the sea with huge towers and castles loaded with arms and ammunition. The outer curtain has four doors corresponding to the main doors of the wall (Ibn Battuta, 1987; Ibn Jubayr, 2003).

Mohammed Ali Pasha never cared about the city wall and castles. Nevertheless, Rashid's gateway stood tall and neglected until he began to crack in 1882, and disappeared completely in 1885 . He and his successors built many defense buildings (Tabaih), each separated by an average of three kilometers. One of the most prominent of these is Tabaih Al-Nahasin, which is located in the maritime Shallalat garden area. It consists of two regular floors and was built of stones (Al-Din Sameh, 1982).

\subsection{Tabaih Al-Nahasin}

Located in the Northern Shallalat garden, it is an ancient tomb built by Mohammad Ali Pasha in the early ninth century and called "Tombstones of Jews" adjacent to Jewish tombs, located on an area of 627 meters. It 
represented a defensive point for the city of Alexandria, as well as a factory for the army's brass machines such as armor and Helmets, and some weapons. Tabaih AlNahasin over-looks Salah Mustafa Street (formerly Sultan Hussein Street). The rulers of Egypt were keen to supply the castles them with guns, so Khedive Ismail imported 200 cannons and distributed on the coast along the coast of Alexandria to the coast of Port Said (Al-Din Sameh, 1982).

It is a rectangular building consisting of two floors. It has four facades. The main façade is the southern façade. The building is consists of two floors. The first floor has four openings. The second floor contains five rectangular openings. The current entrance opens to the east and leads to an open courtyard, to the surface. Currently, it is used as a headquarters for the Department of Archaeological Documentation. AlTabiya border is the sea border. Youth Center Shallalat, Sultan Hussain Kamel Street and the western border is 5 meters from the Shallalat garden of the youth center (Al-Amri and Ibn Yahya, 1986), (Photo 3).

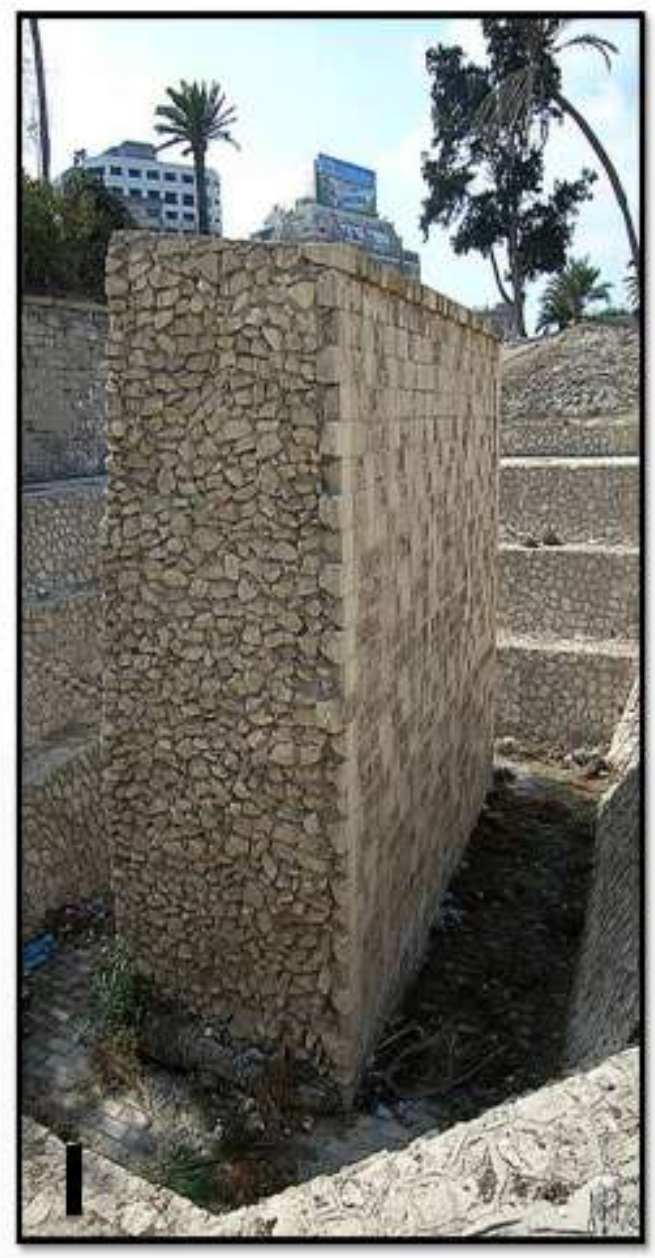

Photo 2. Alexandria Wall in the parts of Shallalat garden:

(1 and2) The Southern Shallalat garden.

(3 and 4) The Northern Shallalat garden. 

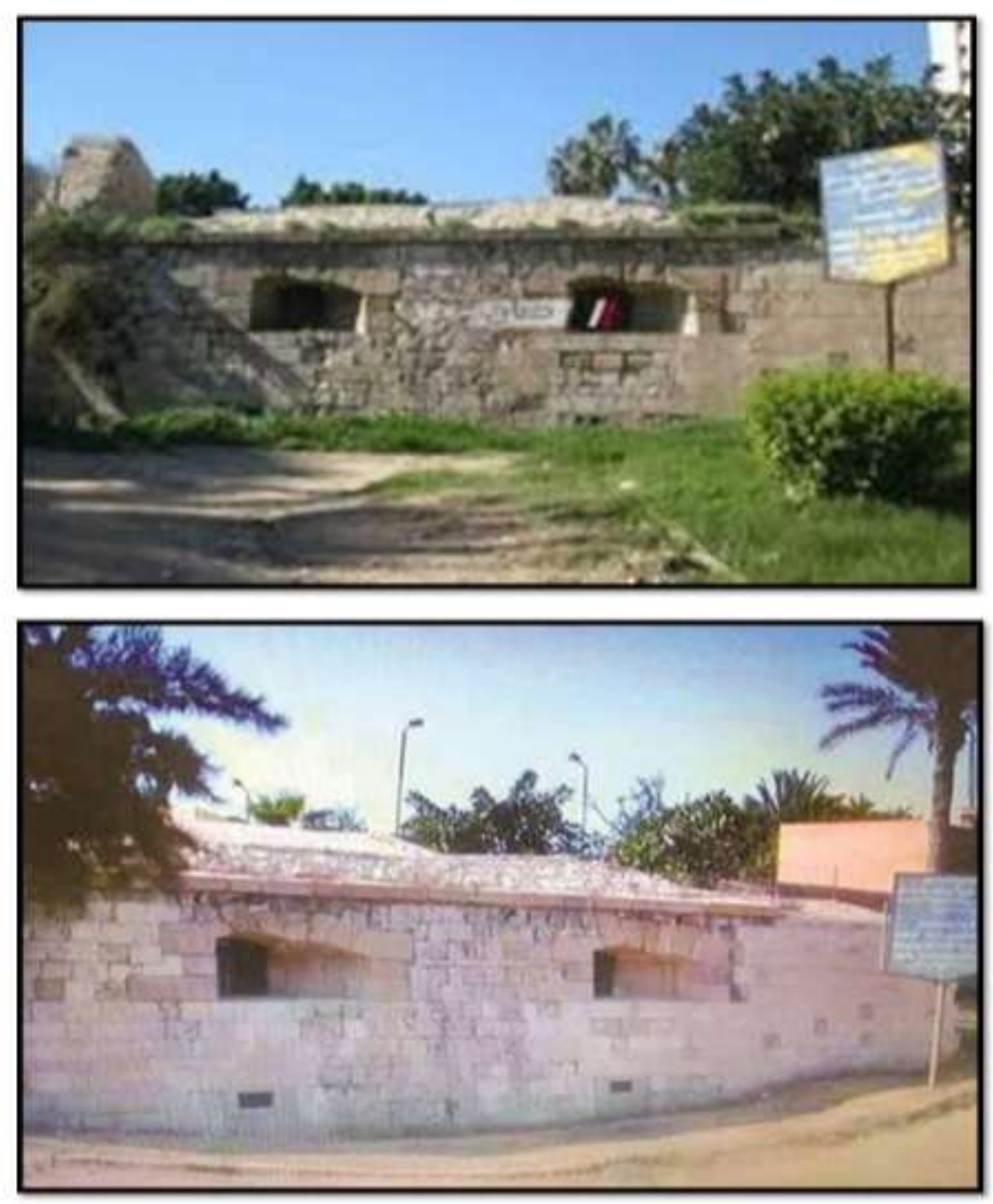

Photo 3. Tabaih Al-Nahasin (The Northern Shallalat garden)

\subsection{Cistern Abn El-Nabih}

Water storage is one of the most important public facilities for communities away from water, for the necessity of securing their water needs. Tanks are two types: public and private, where public tanks are allocated to store water and distribute it in the city. This is similar to the municipal water stations of the present day. Private tanks are used to serve a particular facility, usually smaller.

The people of Alexandria relied on fresh water, which reaches the city through a Gulf that was drilled in the Nile River. From this bay, artificial channels were channeled into the water tanks of the city until the $19^{\text {th }}$ century. Most tanks consisted of two, three, or four levels in high parts of the city. They are rock-cut or multi-shaped, irregular, square, round or angular. These many forms make a person imagine their existence, since some of them are very small and very large, which are likely to be public tanks. The most prominent archaeological tanks located in Alexandria, "Cistern Ibn El-Nabih" (Hertz Pasha, 1898).

The latter is semi-square, consisting of three floors of pillars, each floor with 16 pillars, each four pillars a single row, and these columns are connected with granite struts (Photo 4).

The pillars are based on the walls of the tank by means of pillars supports. The northern wall has an eastern barrack with a water jug, and the second level is similar to the first one. The third level of the tank, which is the holder of the roof, contains pillars of type 
blown, and between these pillars the vaults cross-section of the roof. There were three water outlets in the tank. This tank is one of the masterpieces of water installations in Islamic architecture for its greatness and precision (Ibn Battuta, 1987; Ibn Jubayr, 2003).
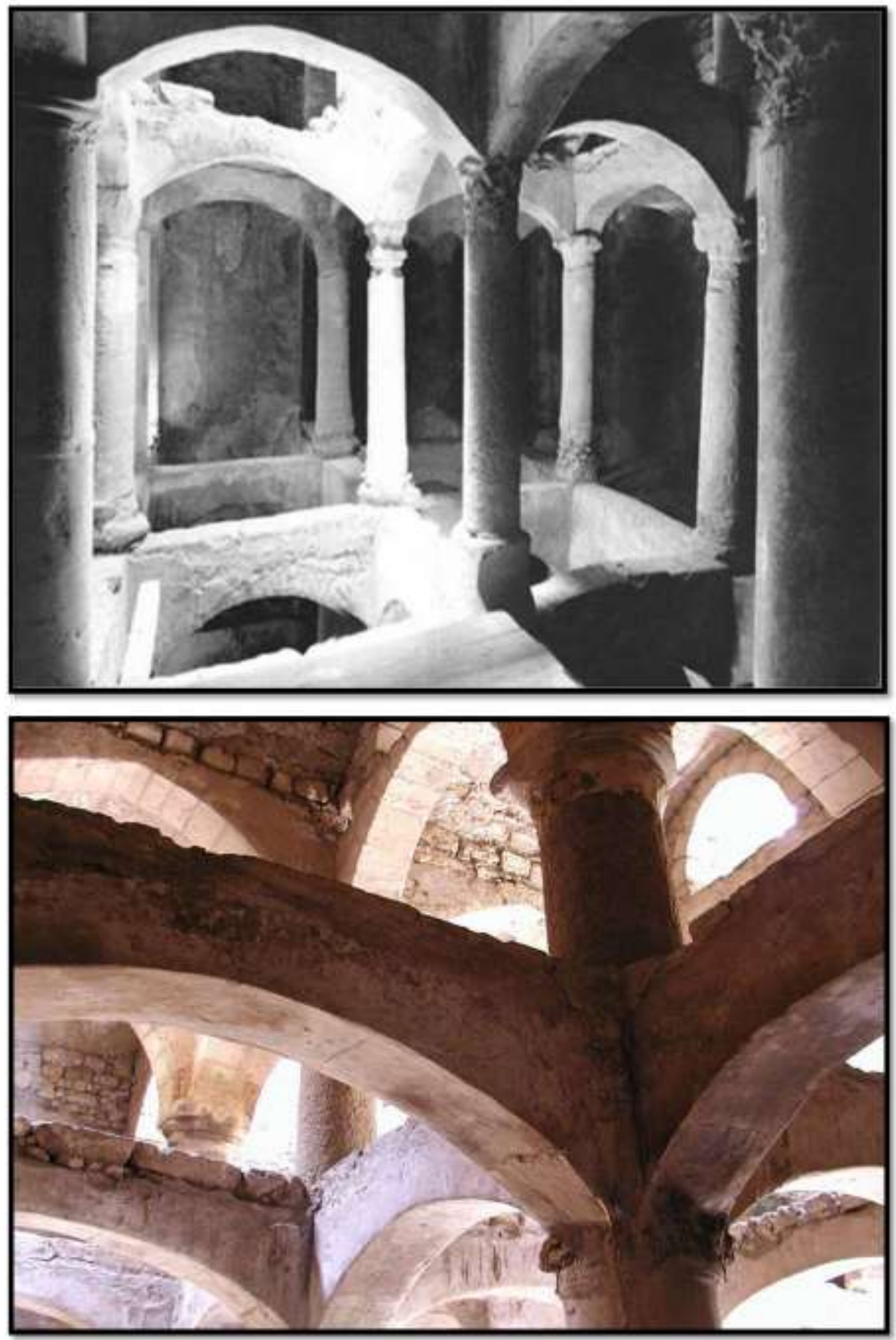

Photo 4. Cistern Abn El-Nabih (The Northern Shallalat garden) 


\subsection{Plant surveying}

The area of the garden is about 28.5 feddans divided into two main sections (Northern Shallalat - Southern Shallalat). The garden contains some plant groups, but it lacks a lot of plants to complete the groups in the garden and to restore the beauty and splendor of the historic garden (SIS, 2014), (Photo 5).

The garden contains many plant groups such as trees, shrubs, climbers, palms and succulent. These groups belong to 33 families, 59 genera and 79 species. The plant groups planted in the Shallalat garden are of high value due to the high age and the few numbers in the Alexandria city, for example, Enterolobium timbova, Syzygium cumini, Kigelia pinnata, Ficus eriobotroides, Ficus religiosa, Ficus macrophylla and Ficus benghalensis tree is more than 200 years old (SIS, 2014), (Photo 6).

The number of cultivated species in Shallalat Garden representing which species have survived and what changes have occurred during the last decades, provide the basis for examining the long term efficiency and effectiveness of planting and management plans. The data presented in Table (1) show the recorded cultivated perennial species during this study (Khalifa and Loutfy, 2006).

The data represented in Table (2), showed that, the most common families were Arecaceae which contains (7) genera with $11.865 \%$ of the total genera in the garden, followed by family Fabaceae which contains (6) genera with $10.170 \%$, followed by families Agavaceae,
Apocynaceae and Malvaceae which contain (3) genera with $5.080 \%$, followed by families Anacardiaceae, Araliaceae, Compositae, Cupressaceae, Dracaenaceae, Euphorbiaceae, Moraceae, Myrtaceae and Verbenaceae which contain (2) genera with $3.390 \%$, followed by families Acanthaceae, Aizoaceae, Araucariaceae, Asparagaceae, Asteraceae, Bignoniaceae, Bombacaceae, Casuarinaceae, Cycadaceae, Gramineae, Meliaceae, Musaceae, Nyctaginaceae, Pinaceae, Plumbaginaceae, Rhamnaceae, Rosaceae, Rutaceae and Tropaeolaceae which contain (1) genus with $1.695 \%$, respectively.

The data represented in Table (2), showed that, The most common families were Moraceae contains (12) species with $15.190 \%$ of the total species in the garden, followed by family Arecaceae contains (9) species with $11.390 \%$, followed by families Agavaceae and Fabaceae contains (6) species with $7.600 \%$, followed by families Apocynaceae and Malvaceae contains (4) species with $5.060 \%$, followed by families Euphorbiaceae, Rutaceae and Varbenaceae contains (3) species with $3.790 \%$, followed by families Anacardiaceae, Araliaceae, Compositae, Cupressaceae, Dracaenaceae and Myrtaceae contains (2) species with $2.530 \%$, followed by families Acanthaceae, Aizoaceae, Araucariaceae, Asparagaceae, Asteraceae, Bignoniaceae, Bombacaceae, Casuarinaceae, Cycadaceae, Gramineae, Meliaceae, Musaceae, Nyctaginaceae, Pinaceae, Plumbaginaceae, Rhamnaceae, Rosaceae and Tropaeolaceae contains (1) species with $1.265 \%$, respectively.

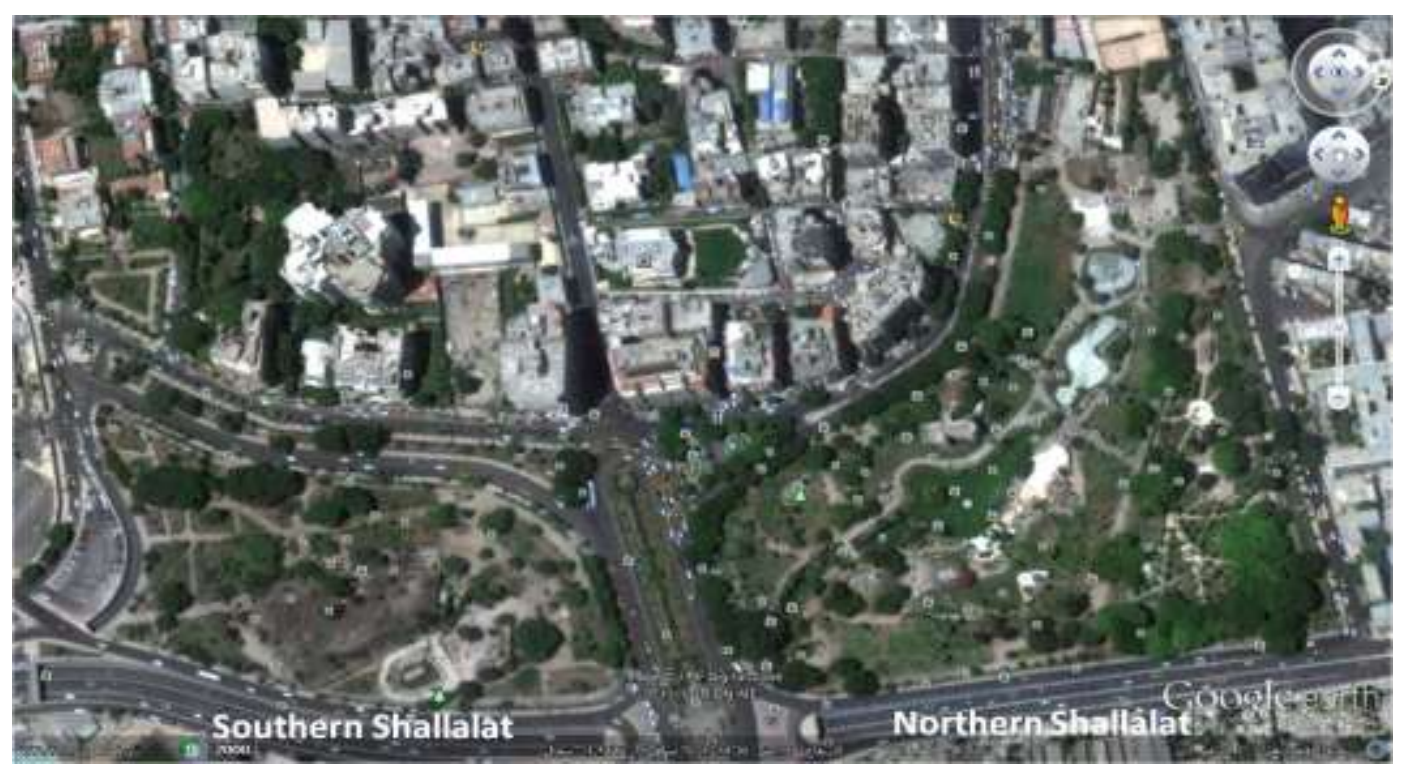

Photo 5. Garden Parts (Northern Shallalat and Southern Shallalat). 

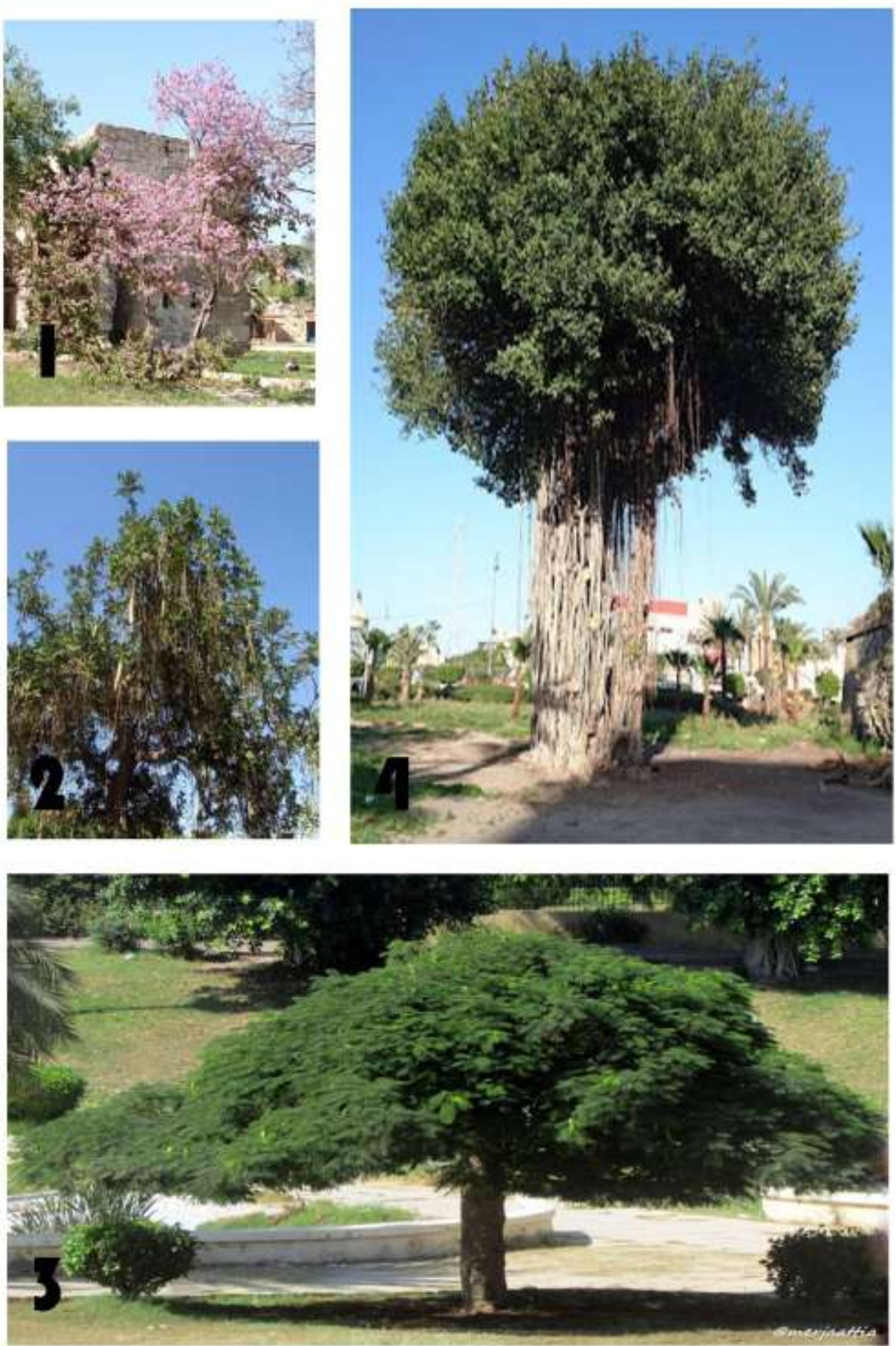

Photo 6. (1) Bauhinia purpurea L, (2) Kigelia pinnata Jacq, (3) Delonix regia (Bojer) raf. and (4) Ficus benghalensis $\mathrm{L}$. (more than 200 years old) 
Table 1. List of plant families, genera, species, and number in the Shallalat garden in the season of 2019.

\begin{tabular}{|c|c|c|c|}
\hline No. & Family & Botanical name & Arabic name \\
\hline 1 & Acanthaceae & Adhatoda yasica $\mathrm{L}$. & بستاشيا بيضاء \\
\hline \multirow{5}{*}{2} & \multirow{5}{*}{ Agavaceae } & Agave attenuate Salm-Dyck & آجاف (صبار عادى) \\
\hline & & Agave americana $\mathrm{L}$. var. marginata Trel. & آجاف آمريكى \\
\hline & & Sansevieria trifasciata Prain & صبار جلد النمر أخضر \\
\hline & & Yacca aloifolia $\mathrm{L}$. & يوكا خضراء \\
\hline & & Yacca filamentosa variegata & يوكا مبرقشتة \\
\hline 3 & Aizoaceae & Aptenia cordifolia & غسول أسبانى \\
\hline \multirow{2}{*}{4} & \multirow{2}{*}{ Anacardiaceae } & Mangifera indica $\mathrm{L}$. & مانجو \\
\hline & & Schinus terebinthifolius Raddi. & فلفل عريض الأوراق \\
\hline \multirow{2}{*}{5} & \multirow{2}{*}{ Araliaceae } & Schefflera arboricola (Hayata) Merr. & شفليرا \\
\hline & & Sciadophyllum pulchrum (hort.) Hook. & آراليا مخمسة \\
\hline 6 & Araucariaceae & Araucaria heterophylla salisb. & آروكاريا عيد المبلاد \\
\hline \multirow{9}{*}{7} & \multirow{9}{*}{ Arecaceae } & Chamaerops humilis L. & نخيل كاميروبس \\
\hline & & Washingtonia robusta H.A.wendi. & واشنجتونيا مفرد \\
\hline & & Washingtonia filifera L. (Lind.) ex Andre. H. wendi. & واشنجتونيا مجوز \\
\hline & & Sabal palmetto (walter) Lodd. & نخيل سابال (ذيل الطاووس) \\
\hline & & Phoenix dactylifera $\mathrm{L}$. & نخيل بلح رئ \\
\hline & & Phoenix canariensis Hort. ex chabaud & 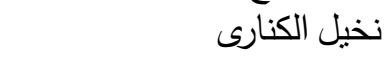 \\
\hline & & Roystonea regia (HBK) Cook & نخيل ملوكى \\
\hline & & Hyphaene thebaica (L) Mart. & ن الديل \\
\hline & & Livistona chinensis (Jacq.) R. Br. ex Mart. & ليفستونيا صبنى \\
\hline \multirow{4}{*}{8} & \multirow{4}{*}{ Apocynaceae } & Thevetia nerifolia (Pers.) K. Schum. & تفيتيا (برتقالى) \\
\hline & & Acokanthera oblongifolia (Hochst) Codd. & أكوكنثرا \\
\hline & & Nerium oleander L. & دفلة خضراء \\
\hline & & Nerium oleander var.varigata & دفلة صفراء \\
\hline 9 & Asparagaceae & Asparagas plumosus Bak. & أسبرجس ناعم \\
\hline 10 & Asteraceae & Gazania rigens (L.) Gaertn. & جازانيا \\
\hline 11 & Bignoniaceae & Kigelia pinnata Jacq. & أبو النجف (المشطورة) \\
\hline 12 & Bombacaceae & Chorisia speciosa A. St. Hil. & كوريزيا روز (مهرشة الفيل) \\
\hline 13 & Casuarinaceae & Casuarina cunninghamiana Miq. & كازورينا حمراء \\
\hline \multirow{2}{*}{14} & \multirow{2}{*}{ Compositae } & Dimorphatheca ecklonis & ديمورفوتيكا بيضاء \\
\hline & & chrysanthemum maximum & مرجريت \\
\hline \multirow{2}{*}{15} & \multirow{2}{*}{ Cupressaceae } & Platycladus orientalis (L.f.) Franco. & \\
\hline & & Cupressus macrocarpa Hartw. & سرو ليمون \\
\hline 16 & Cycadaceae & Cycas revoluta Thunb. & سيكس (ذيل السمكة) \\
\hline \multirow{2}{*}{17} & \multirow{2}{*}{ Dracaenaceae } & Dracaena marginata Lam. & دراسينا مارجناتا \\
\hline & & Beaucarnea recurvata Lem. & زلوعة (دراسينا قلة) \\
\hline \multirow{3}{*}{18} & \multirow{3}{*}{ Euphorbiaceae } & Acalypha wilkesiana Muell. & آكاليفا حمراء مفرد \\
\hline & & Euphoebia tirucallii & صبار أم اللبن (كلاكيا) \\
\hline & & Euphorbia pulcherrima & بنت القنصل \\
\hline
\end{tabular}


Cont. Table 1. List of plant families, genera, species, and number in the Shallalat garden in the season of 2019.

\begin{tabular}{|c|c|c|c|}
\hline No. & Family & Botanical name & Arabic name \\
\hline \multirow{6}{*}{19} & \multirow{6}{*}{ Fabaceae } & Albizzia lebbek (L.) Benth. & اللبخ (ذقن الباشا) \\
\hline & & Delonix regia (Bojer) raf. & بوانسيانا (زهرة الجنة) \\
\hline & & Bauhinia purpurea $\mathrm{L}$. & بوهينيا بنفسجى \\
\hline & & Enterolobium timbova & انترولوبيم \\
\hline & & Cassia nodosa $\mathrm{L}$. & 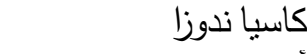 \\
\hline & & Erythrina humeana $\mathrm{L}$. & 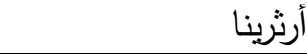 \\
\hline 20 & Gramineae & Cynodon dactylon & نجيل بلدى \\
\hline \multirow{4}{*}{21} & \multirow{4}{*}{ Malvaceae } & Hibiscus schizopetalis (Mast.)Hook. F. & هبسكس نجف \\
\hline & & Malvaviscus arboreus Cav. & هبسكس مقفول (بلحة) \\
\hline & & Hibiscus rosa sinensis & هبسكس مفتوح \\
\hline & & Althaea rosea $\mathrm{L}$. & خطمية عمودية \\
\hline 22 & Meliaceae & Melia azedaracht $\mathrm{L}$. & زنزلخت \\
\hline \multirow{12}{*}{23} & \multirow{12}{*}{ Moraceae } & Ficus elastic Roxb. Ex Hornem. var.decora & فيكس الاسنتيكا ديكورا \\
\hline & & Ficus virens var. sublanceolata & فيكس فيرنس عريض \\
\hline & & Ficus virens Ait. & فيكس فيرنس رفيع \\
\hline & & Ficus nitida $\mathrm{L}$. & فيكس عادى \\
\hline & & Ficus macrophylla Desf ex pers. & فيكس ماكروفيلا \\
\hline & & Ficus benghalensis $\mathrm{L}$. & 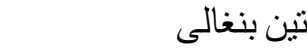 \\
\hline & & Ficus eriobotroides Huteh. & فيكس بشملة \\
\hline & & Ficus benjamina $\mathrm{L}$. & 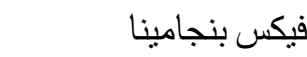 \\
\hline & & Ficus microcarpa L.f. Cv. hawaii & فيكس هاواى \\
\hline & & Ficus religiosa $\mathbf{L}$. & فيكس آبو لسان \\
\hline & & Ficus benjamina var. Gold & فيكس بينجامينا جولا \\
\hline & & Morus nigra $\mathrm{L}$. & توت أسود \\
\hline 24 & Musaceae & Sterlitzia reginae & عصفور الجنة الصغير \\
\hline \multirow{2}{*}{25} & \multirow{2}{*}{ Myrtaceae } & Syzygium cumini (L.) Skeels & 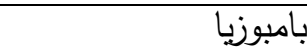 \\
\hline & & Psidium guajava $\mathbf{L}$. & جوافة \\
\hline 26 & Nyctaginaceae & Bougainvillea glabra choisy ex DC. & جهمية \\
\hline 27 & Pinaceae & Pinus palustris Miller & صنوبر طويل الأوراق \\
\hline 28 & Plumbaginaceae & Plumbago auriculata Lam. & بلمباجو آزرق \\
\hline 29 & Rhamnaceae & Zizyphus spina-christi L. (Dsef.) & 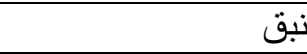 \\
\hline 30 & Rosaceae & Rosa pendulina $\mathbf{L}$. & 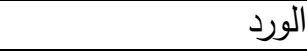 \\
\hline \multirow{3}{*}{31} & \multirow{3}{*}{ Rutaceae } & Citrus limon (L.) Burn. & موالح (ليمون حلو) \\
\hline & & Citrus sinensis (L.) Osbeck. & موالح (برتقال) \\
\hline & & Citrus reticulate Blanco. & موالح (يوسفى) \\
\hline 32 & Tropaeolaceae & Tropaeolum majus $\mathrm{L}$. & آبو خنجر \\
\hline \multirow{3}{*}{33} & \multirow{3}{*}{ Verbenaceae } & Duranta plumeri jacp. & دورانتا خضراء \\
\hline & & Duranta plumeri variegata & دورانتا بيضاء \\
\hline & & Lantana camara $\mathrm{L}$. & لانتانا كمارا \\
\hline
\end{tabular}

Nomenclature: Badr (2003), Badr (2013), Badr (2014) and Heneidy (2010) 
Table 2. The numbers of genera, species and their percentages in the Shallalat garden in the season of 2019.

\begin{tabular}{|c|c|c|c|c|c|}
\hline \multirow{2}{*}{ No. } & \multirow{2}{*}{ Family } & \multicolumn{2}{|c|}{ Genus } & \multicolumn{2}{|c|}{ Species } \\
\hline & & No. & $(\%)$ & No. & $(\%)$ \\
\hline 1 & Acanthaceae & 1 & 1.695 & 1 & 1.265 \\
\hline 2 & Agavaceae & 3 & 5.080 & 5 & 6.330 \\
\hline 3 & Aizoaceae & 1 & 1.695 & 1 & 1.265 \\
\hline 4 & Anacardiaceae & 2 & 3.390 & 2 & 2.530 \\
\hline 5 & Araliaceae & 2 & 3.390 & 2 & 2.530 \\
\hline 6 & Araucariaceae & 1 & 1.695 & 1 & 1.265 \\
\hline 7 & Arecaceae & 7 & 11.865 & 9 & 11.390 \\
\hline 8 & Apocynaceae & 3 & 5.080 & 4 & 5.060 \\
\hline 9 & Asparagaceae & 1 & 1.695 & 1 & 1.265 \\
\hline 10 & Asteraceae & 1 & 1.695 & 1 & 1.265 \\
\hline 11 & Bignoniaceae & 1 & 1.695 & 1 & 1.265 \\
\hline 12 & Bombacaceae & 1 & 1.695 & 1 & 1.265 \\
\hline 13 & Casuarinaceae & 1 & 1.695 & 1 & 1.265 \\
\hline 14 & Compositae & 2 & 3.390 & 2 & 2.530 \\
\hline 15 & Cupressaceae & 2 & 3.390 & 2 & 2.530 \\
\hline 16 & Cycadaceae & 1 & 1.695 & 1 & 1.265 \\
\hline 17 & Dracaenaceae & 2 & 3.390 & 2 & 2.530 \\
\hline 18 & Euphorbiaceae & 2 & 3.390 & 3 & 3.790 \\
\hline 19 & Fabaceae & 6 & 10.170 & 6 & 7.600 \\
\hline 20 & Gramineae & 1 & 1.695 & 1 & 1.265 \\
\hline 21 & Malvaceae & 3 & 5.080 & 4 & 5.060 \\
\hline 22 & Meliaceae & 1 & 1.695 & 1 & 1.265 \\
\hline 23 & Moraceae & 2 & 3.390 & 12 & 15.190 \\
\hline 24 & Musaceae & 1 & 1.695 & 1 & 1.265 \\
\hline 25 & Myrtaceae & 2 & 3.390 & 2 & 2.530 \\
\hline 26 & Nyctaginaceae & 1 & 1.695 & 1 & 1.265 \\
\hline 27 & Pinaceae & 1 & 1.695 & 1 & 1.265 \\
\hline 28 & Plumbaginaceae & 1 & 1.695 & 1 & 1.265 \\
\hline 29 & Rhamnaceae & 1 & 1.695 & 1 & 1.265 \\
\hline 30 & Rosaceae & 1 & 1.695 & 1 & 1.265 \\
\hline 31 & Rutaceae & 1 & 1.695 & 3 & 3.790 \\
\hline 32 & Tropaeolaceae & 1 & 1.695 & 1 & 1.265 \\
\hline 33 & Verbenaceae & 2 & 3.390 & 3 & 3.790 \\
\hline
\end{tabular}

\subsection{Air Pollution Tolerance Index (APTI)}

In the present study, most plants collected from the experimental site used for the air pollution tolerance index (APTI) study. Air Pollution Tolerance Index (APTI) is calculated for 35 plant species growing in shallalat garden and the data is presented in Table (3). All biochemical parameters that are analyzed for APTI play significant role to determine resistivity and susceptibility of plant species. Ascorbic acid is important in cell wall synthesis, photosynthetic carbon fixation and cell division (Klump et al., 2001), $\mathrm{pH}$ as an indicator for sensitivity to air pollution (Singh et al, 1997), total chlorophyll is also related to ascorbic acid productivity. Air pollution in urban and industrial areas may get adsorbed, absorbed, accumulated or integrated in the plant body and if toxic, may injure them in various ways. The level of injury will be high in sensitive species and low in tolerant ones. 
Table 3. The mean of Air Pollution Tolerance Index (APTI) of plant species in Shallalat garden, Alexandria city in the two seasons of 2019 and 2020.

\begin{tabular}{|c|c|c|c|c|c|c|c|c|c|c|c|}
\hline \multirow{2}{*}{ No. } & \multirow{2}{*}{ Botanical name } & \multicolumn{5}{|c|}{2019} & \multicolumn{5}{|c|}{2020} \\
\hline & & $\mathbf{A}$ & $\mathbf{T}$ & pH & RWC & APTI & $\mathbf{A}$ & $\mathbf{T}$ & pH & RWC & APTI \\
\hline \multicolumn{12}{|c|}{ Palms } \\
\hline 1 & Chamaerops humilis L. & 2.81 & 3.80 & 4.40 & 76.98 & 30.80 & 2.86 & 3.80 & 4.47 & 76.18 & 31.33 \\
\hline 2 & Phoenix canariensis Hort. ex chabaud & 4.76 & 4.28 & 5.30 & 75.96 & 53.32 & 4.81 & 4.29 & 5.37 & 75.14 & 54.04 \\
\hline 3 & Phoenix dactylifera $\mathrm{L}$. & 5.00 & 4.34 & 5.47 & 72.66 & 56.39 & 5.05 & 4.35 & 5.54 & 71.86 & 57.19 \\
\hline 4 & Sabal palmetto (walter) Lodd. & 2.76 & 4.00 & 4.64 & 76.05 & 31.52 & 2.81 & 4.00 & 4.71 & 75.25 & 32.06 \\
\hline 5 & Washingtonia robusta H.A.wendi. & 4.14 & 4.46 & 6.17 & 73.88 & 51.49 & 4.19 & 4.46 & 6.24 & 73.08 & 52.22 \\
\hline \multicolumn{12}{|c|}{ Trees } \\
\hline 1 & Thevetia nerifolia (Pers.) K. Schum. & 3.73 & 3.40 & 7.30 & 54.86 & 45.50 & 3.78 & 3.40 & 7.38 & 54.06 & 46.24 \\
\hline 2 & Chorisia speciosa A. St. Hil. & 1.75 & 1.84 & 6.30 & 80.85 & 22.40 & 1.80 & 1.85 & 6.37 & 80.05 & 22.84 \\
\hline 3 & Delonix regia (Bojer) raf. & 2.04 & 4.91 & 6.83 & 72.85 & 31.35 & 2.15 & 4.92 & 6.90 & 72.04 & 32.62 \\
\hline 4 & Bauhinia purpurea $\mathrm{L}$. & 1.68 & 2.09 & 6.00 & 66.42 & 20.32 & 1.75 & 2.09 & 6.07 & 65.62 & 20.89 \\
\hline 5 & Cassia nodosa $\mathrm{L}$. & 2.36 & 4.68 & 5.90 & 52.65 & 30.30 & 2.41 & 4.69 & 5.97 & 51.81 & 30.91 \\
\hline 6 & Erythrina humeana L. & 1.96 & 4.65 & 5.53 & 71.05 & 27.12 & 2.01 & 4.65 & 5.61 & 70.24 & 27.69 \\
\hline 7 & Ficus elastic Roxb. Ex Hornem. var.decora & 3.46 & 3.32 & 6.93 & 68.77 & 42.42 & 3.51 & 3.32 & 7.01 & 67.97 & 43.12 \\
\hline 8 & Ficus nitida $\mathrm{L}$. & 2.44 & 2.19 & 7.45 & 93.92 & 32.95 & 2.48 & 2.19 & 7.52 & 93.12 & 33.49 \\
\hline 9 & Ficus benghalensis L. & 2.49 & 1.81 & 8.35 & 82.69 & 33.64 & 2.54 & 1.82 & 8.42 & 81.89 & 34.25 \\
\hline 10 & Ficus benjamina $\mathrm{L}$. & 2.64 & 2.44 & 7.13 & 78.85 & 33.20 & 2.69 & 2.45 & 7.20 & 78.04 & 33.81 \\
\hline 11 & Ficus virens Ait. & 4.63 & 1.76 & 8.03 & 81.59 & 53.57 & 4.69 & 1.76 & 8.10 & 80.79 & 54.38 \\
\hline 12 & Ficus religiosa $\mathrm{L}$. & 4.70 & 1.74 & 7.73 & 73.06 & 51.89 & 4.74 & 1.75 & 7.80 & 72.26 & 52.59 \\
\hline 13 & Ficus eriobotroides Huteh. & 5.21 & 1.77 & 6.80 & 70.39 & 51.76 & 5.26 & 1.77 & 6.88 & 69.59 & 52.51 \\
\hline 14 & Albizzia lebbek (L.) Benth. & 1.80 & 1.58 & 6.30 & 75.58 & 21.81 & 1.84 & 1.59 & 6.37 & 74.78 & 22.18 \\
\hline 15 & Schinus terebinthifolius Raddi. & 3.58 & 2.77 & 6.73 & 83.66 & 42.41 & 3.63 & 2.77 & 6.80 & 82.86 & 43.10 \\
\hline \multicolumn{12}{|c|}{ Fruit trees } \\
\hline 1 & Mangifera indica $\mathrm{L}$. & 2.34 & 1.18 & 4.63 & 94.97 & 23.14 & 2.39 & 1.19 & 4.71 & 94.17 & 23.53 \\
\hline 2 & Syzygium cumini (L.) Skeels & 2.07 & 7.19 & 6.44 & 68.86 & 35.18 & 2.15 & 7.19 & 6.51 & 68.06 & 36.37 \\
\hline 3 & Morus nigra L. & 1.62 & 2.39 & 5.96 & 86.05 & 22.17 & 1.65 & 2.39 & 6.04 & 85.24 & 22.47 \\
\hline 4 & Psidium guajava $\mathrm{L}$. & 2.01 & 7.47 & 5.73 & 68.86 & 33.50 & 2.06 & 7.47 & 5.80 & 68.06 & 34.21 \\
\hline 5 & Citrus sinensis (L.) Osbeck. & 3.51 & 1.87 & 6.23 & 62.25 & 34.71 & 3.56 & 1.87 & 6.30 & 61.44 & 35.29 \\
\hline
\end{tabular}


Cont. Table 3. The mean of Air Pollution Tolerance Index (APTI) of plant species in Shallalat garden, Alexandria city in the two seasons of 2019 and 2020.

\begin{tabular}{|c|c|c|c|c|c|c|c|c|c|c|c|}
\hline \multirow{2}{*}{ No. } & \multirow{2}{*}{ Botanical name } & \multicolumn{5}{|c|}{2019} & \multicolumn{5}{|c|}{2020} \\
\hline & & $\mathbf{A}$ & $\mathbf{T}$ & pH & RWC & APTI & $\mathbf{A}$ & $\mathbf{T}$ & pH & RWC & APTI \\
\hline \multicolumn{12}{|c|}{ Shrubs } \\
\hline 1 & Acalypha wilkesiana Muell. & 1.95 & 3.21 & 6.03 & 53.17 & 23.38 & 1.96 & 3.22 & 6.10 & 52.37 & 23.55 \\
\hline 2 & Acokanthera oblongifolia (Hochst) Codd. & 3.58 & 3.11 & 7.30 & 62.85 & 43.66 & 3.63 & 3.12 & 7.37 & 62.04 & 44.39 \\
\hline 3 & Duranta plumeri jacp. & 2.73 & 5.60 & 6.23 & 65.89 & 38.97 & 2.78 & 5.60 & 6.30 & 65.09 & 39.66 \\
\hline 4 & Hibiscus rosa sinensis & 3.73 & 4.44 & 6.38 & 53.88 & 45.88 & 3.78 & 4.45 & 6.45 & 53.08 & 46.56 \\
\hline 5 & Lantana camara $\mathrm{L}$. & 2.78 & 6.07 & 6.35 & 63.06 & 40.96 & 2.83 & 6.07 & 6.42 & 62.24 & 41.69 \\
\hline 6 & Malvaviscus arboreus Cav. & 3.81 & 4.35 & 7.73 & 72.98 & 53.40 & 3.86 & 4.35 & 7.80 & 72.18 & 54.20 \\
\hline 7 & Nerium oleander L. & 1.64 & 2.96 & 5.97 & 68.23 & 21.52 & 1.69 & 2.96 & 6.04 & 67.43 & 21.96 \\
\hline \multicolumn{12}{|c|}{ Perennials } \\
\hline 1 & Gazania rigens (L.) Gaertn. & 1.89 & 3.34 & 5.87 & 48.75 & 22.35 & 1.94 & 3.35 & 5.94 & 47.98 & 22.86 \\
\hline \multicolumn{12}{|c|}{ Climbers } \\
\hline 1 & Bougainvillea glabra choisy ex DC. & 3.68 & 6.62 & 6.94 & 41.39 & 54.15 & 3.74 & 6.62 & 7.01 & 40.59 & 55.07 \\
\hline \multirow[t]{2}{*}{2} & Plumbago auriculata Lam. & 2.61 & 5.70 & 6.30 & 53.29 & 36.73 & 2.65 & 5.70 & 6.37 & 52.49 & 37.30 \\
\hline & L.S.D. at 0.05 & 0.029 & 0.007 & 0.009 & 0.017 & 0.776 & 0.030 & 0.009 & 0.019 & 0.013 & 0.582 \\
\hline
\end{tabular}

- $\mathrm{A}=$ Ascorbic acid (mg/g D.W)

- $\mathrm{T}=$ Total chlorophyll (mg/g F.W)

- $\mathrm{PH}=$ Leaf extract $(\mathrm{pH})$

- $\mathrm{RWC}=$ Relative water content $(\%)$ 
The sensitive species help in indicating air pollution and tolerant one help in abatement of air pollution (Flowers, et al 2007). The tolerant species of plants function as pollution "sink" and therefore a number of environmental benefits can be desired by planting tolerant species in polluted areas. For this purpose, evaluation of plants with respect to their tolerance level to air pollution may be essential. To evaluate the tolerance level of plant species to air pollution, According to Singh and Rao, (1983) used four leaf parameters to drive an empirical number indicating the Air Pollution Tolerance Index (APTI). From table (3) it was evident that the plants showed varied degree of tolerance index to air pollution. Thus the present work aims to evaluate the air pollution tolerance index (APTI) of different plant species growing near residential, commercial and industrial area of the city as to provide a particular plant species to grow in respective areas.

Based on the APTI values the plants were conveniently grouped as follows (Kalyani and Singaracharya, 1995).

- APTI value $=$ Response.

- 30 to $100=$ Tolerant.

- 17 to $29=$ Intermediate.

- 1 to $16=$ Sensitive.

$-<1=$ Very sensitive.

Vegetation naturally cleans the atmosphere by absorbing gases and particulate matter through leaves as plant leaf may act as a persistent absorber when exposed to the polluted environment. Sensitive plant species are suggested as bio-indicators (Tripathi et al., 1999; Raina and Sharma, 2006). Bio-indicators may be very useful due to their high sensitivity towards a broad (De Temmerman et al., 2004). Different plant species showed a different behavior for different pollutants and any plant part could be indifferently used as biomonitors (Mingorance et al., 2007). Air pollution tolerance Index is been used in studies like Green belt development Shannigrahi et al., (2004), traffic noise reduction Pathak et al., (2011) and Pollution mitigation at roadside sites and around industries Joshi and Swami (2007) and Krishnaveni et al., (2012). The categorization of the plant species is based on method of Singh and Rao (1983).

\section{CONCLOTION}

Gardens in Egypt are deserted, ignored, rapidly deteriorating and even vanishing in terms of area. Nearly all these parks are historical landscapes, which emphasizes the grave need to keep these parks intact and in proper condition. The main problem with such historically significant parks is that they have been denied proper attention and emphasis, whether from the municipality or individuals of the community. There aren't any clear criteria or a specified process of identifying such significant open spaces, classifying them or conserving them in Egypt. This lack of a methodological as well as practical approach highly increased the rate of deterioration of gardens in Alexandria. In this research, any other historical landscape, the archaeological installations and cultivated plants in shallalat garden should be documented and preserved accordingly, through a municipal entity, a community-based foundation, or individual interested in the field. It is hoped that the significant for any future studies in conserving national gardens.

Plants that are continuously exposed to pollutants leads to accumulation of pollution, integration of pollutants in to their own system, thereby altering the nature of leaf and make them more sensitive. This sensitivity is measured through various biochemical changes and finally to air pollution tolerance index. In our study, all the plants were found to be tolerant and intermediate species.

\section{REFERENCES}

Abd El-Aziz, N. (2012). Designing and Managing Urban Parks to Improve the Quality of Life in the Egyptian Cities, PH.D. Thesis, Cairo University, Cairo, Egypt.

Abd El-Rahman N. (2017). Alexandria's cultural landscapes: Historical parks between originality and deterioration. Transactions on The Built Environment, Vol 170, 73-83.

Abdou Aziz, L.K. (2004). Urban growth in Alexandria, Egypt using remote sensing and GIS . PH.D. Thesid, Newcastle University.

Al-Amri I.F. and S. A. Ibn Yahya (1986). Pathways of sight in the kingdoms of Amazar. French Institute of Oriental Archeology, Cairo.

Al-Din Sameh K. (1982). Architecture in the Origin of Islam (in Arabic). Egyptian General Book Authority, pp. 157154.

Al-Falaki M.P. (1967). Ancient Alexandria (in Arabic). Publishing House of Culture, Alexandria, Egypt, pp. 8954.

Badr M.D. (2003). Encyclopedia of Trees and Environment. Monshaat Al-Maarif (in Arabic), Alexandria, Egypt, pp.747-824.

Badr M.D. (2013). Encyclopedia of Shrubs. Monshaat AlMaarif (in Arabic), Alexandria, Egypt.

Badr M.D. (2014). Encyclopedia of Palms and Palm-like. Monshaat Al-Maarif (in Arabic), Alexandria, Egypt.

Bailey L. H. (1947). The standard cyclopedia of Horticulture. Vol I (A-E), Vol IT (F-O), Vol III (P-Z). New York, The Macmillan Company. Pp. 3639.

Bajaj K.L. and G. Kaur (1981). Spectrophoto-metric Determination of L. Ascorbic Acid in Vegetable and Fruits. Analyst. 106: 117-120. 
Bell, H.I. (1927). Alexandria. J. Egypt Archaeol, 13(3/4), pp. 171-184.

Beveridge, C. and P. Rocheleau (1998). Frederick Law Olmsted: Designing the American Landscape. New York, New York Universe Publishing. ISBN 0-7893-0228-4.

Boulos L. (1999). Flora of Egypt. vol. I. Al-Hadara Publishing. Cairo, Egypt. Pp.4I9.

Boulos L. (2000). Flora of Egypt. vol. 2. Al-Hadara Publishing. Cairo, Egypt. Pp.352.

Boulos L. (2002). Flora of Egypt. vol. 3. Al-Hadara Publishing. Cairo, Egypt. Pp.373.

Boulos L. (2005). Flora of Egypt. vol. 4. Al-Hadara Publishing. Cairo, Egypt. Pp.617.

De. Temmerman, L.; J.N.B. Bell; J. P. Garreo; A. Kiumpp;A.G. Krauseand and G.M. Tonneijck (2004). Biomonitoring of air pollution with plants-Assesment of air pollution in some trees 549 Considerations for the future. In: Urban air pollution, bioindication and environmental awareness (Eds.: A. Klumpp, W. Ansel and G.Klumpp). Cuvillier Verlrg, Gottingen. p337-373.

EL-Torky, M.G.;T. M. EZZ; H. F. EL-Tayeb and A. A. Arafa (2013). The History and Floristic Composition of Antoniades Botanical Garden in Alexandria, Egypt. J. Adv. Agric. Res. (Fac. Agric. Saba Basha), 18 (4): 680707.

Flowers M.D., E.L. Fiscus, K.O.Burkey (2007). Photosynthesis, chlorophyll fluorescence and yield of snap bean (Phaseolus vulgaris L) genotype differing in sensitivity to Ozone. Environ. Exp. Bot. 61: 190-198.

Hamdy R. (2010). A study of plant distribution in nine historic gardens in Egypt (in Arabic). Gard Hist, 28(2), pp. 267314.

Heneidy S.Z. (2010). Plant Atlas of the Botanic Garden Faculty of Science, Alexandria University. Monshaat AlMaarif (in Arabic), Alexandria, Egypt, pp.429-443.

Hertz Pasha (1898). Tankers of Alexandria (in Arabic). the brochure of the Committee for the Conservation of Arab Antiquities, supplement of report 238.

Ibn Battuta M. (1987). The travels of Ibn Battuts (in Arabic). Dar Ehya El-Elom, Beirut. p. 175.

Ibn Jubayr A.M. (2003). Ibn Jubayr Journey (in Arabic). Dar El-Kotob El-Almiya, Beirut. p. 185.

Ilbert R. (1996). Alexandrie, 1830-1930, Histoire D'une Communité Citadaine, (Cairo: Institut Fran, ais d'Archéologie Orientale). (2):Pp. 919.

Joshi, P.C. and A. Swami (2007). Physiological responses of some trees under roadside automobile pollution stress around city of Haridwar, India. Environmentalist, 27: 365374.

Khalifa, S.F. and M.H. Loutfy (2006). Ornamental cultivated plant collection Special edition in the occasion of the First International Conference, "Strategy of Botanic Gardens" May 10-12, 2006 Flora and Taxonomy Research Unit, Agriculture Museum, Dokki, Giza, Egypt.
Kalyani Y. and M. A. Singaracharya (1995). Bio monitoring of air pollution in Warangal city, Andhra Pradesh, Acta Botanica indica, 23(1):21-24.

Klump G, Furlan CM, M. Domingos (2001). Response of stress indicators and growth parameters of tibouchina pulchra logn. Exposed to air and soil pollution near the industrial complex of cubatao, Brazil. Sci. Total Environ., 246: 79-91.

Krishnaveni, M., S. Usha and R. Kowsalya (2012). Evaluation of air pollution tolerance index of selected herbal tree and plant species (leaves) with in the Periyar Uni-versity campus, Salem, Tamil nadu, India. Journal of Pharmacy Research, 5(6): 3219-3222.

Mingorance, M.D., B. Valdes and S.R. Oliva (2007). Strategies of heavy metal uptake by plants growing under industrial emissions. Environ. Intern., 33: 514-520.

Moran, R. (1982). Formulae for determination of chlorophyllous pigments extracted with N-N dimethylformamide. plant physiol 69(6):1376-1381.

Pathak, V., B.D. Tripathi, and V.K. Mishra (2011). Evaluation of anticipated performance index of some tree species for green belt development to mitigate traffic gen-erated noise. Urban Forestry and Urban Greening, 10(1): 61-66.

Raina, A.K. and A. Sharma (2006). Assessment of air pollution and its impact on the leaves of some plant species. Pollut. Res., 25: 543-547.

SAS Institute 2002. SAS User Guide and Program 20 Version 9.0.38. Cary, North Carolina, USA.

S.F.C., Scholars of the French Campaign (1992). Encyclopedia of the Description of Egypt (Zuhair AlShayeb), Third Edition, Ministry of Culture, Cairo, Egypt.

Saad El-Din M., G.L. Steen and A. De Luca (1993). Alexandria: The Site and the History, New York University Press: New York.

Shannigrahi, A.S., T. Fukushima, and R.C. Sharma, (2004). Anticipated air pollution tolerance of some plant species considered for green belt development in and around an industrial/urban area in India: an overview. Internation-al Journal of Environmental Studies, 61(2): 125-137.

Singh S. K. and D. N. Rao (1983). Evaluation of plants for their tolerance to air pollution. In Proceedings of symposium on air pollution control, 1: 218-224.

Singh S.K., D.N. Rao, M. Agrawal, J.Pandey (1997). Air pollution Tolerance index of Plants. J. Environ. Manag. 32: $45-55$.

SIS, State Information Service (2014). Gardens of Alexandria.

Snedecor, G. W. and W. Cochran. 1989. Statistical Methods, $8^{\text {th }}$ ed. Edition, Iowa State University Press. Ames. Iowa. USA.

Tackholm V. (1974). Students' Flora of Egypt. Second edition Published by Cairo University Printed by Cooperative Printing Company Beirut. Pp 887.

Tripathi, A.; D.S. Tripathi and V.Prakash (1999). Phytomonitoring and NOx pollution around silver refineries. Environ. Pollut., 25: 403-410. 


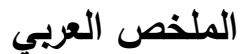

حصر وتوثيق النباتات المنزرعة وتقييم تلوث الهواء في الحدائق التاريخية في الإسكندرية، مصر (أ) حديقة الشتلاتات

$$
\text { نادر أحمد الثنهورى }
$$

يتم تجميع ملامح الحديقة في شكل مجموعتين. يتكون

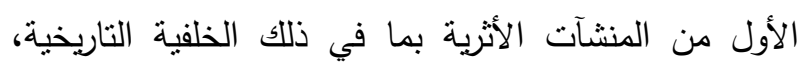

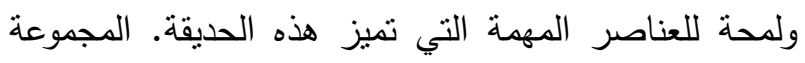
الثانية تتكون من المساحات النباتية المزروعة في الحديقة. تحتوي الحديقة على مجموعات نباتية عديدة مثل الأثجار

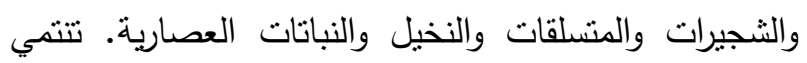

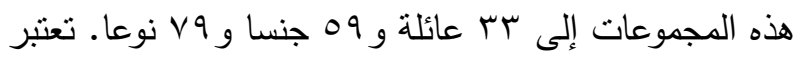

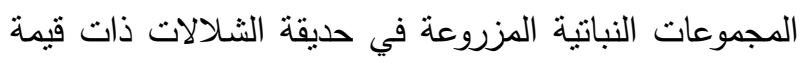
عالية بسبب نقدمها فى العمر وقلة أعدادها في مدينة الإسكندرية. تحتوي الحديقة على بعض المجموعات النباتية ولكنها تفتقر إلى الكثير من النباتات لتكمل المجموعات

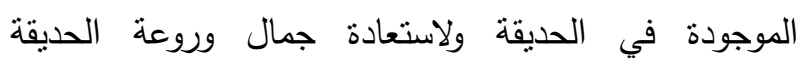
التاريخية. بالإضافة إلى أن الحديقة تقع في وسط الإسكندرية، مما يعني أنها تقع في منطقة مرورية عالية الكثافة، وبالثالي تم حساب مؤشر تحمل تلوث الهواء (APTI) للنباتات المختلفة المزروعة في الحديقة.
تعد الإسكندرية واحدة من أكبر المدن في مصر من حيث

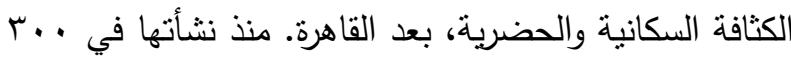
قبل الميلاد، كانت واحدة من أكبر المدن الكبرى في العالم القديم، ثقافيا وفكريا وسياسيا واقتصاديا. نتعكس البيئة الحضرية الأنيقة في الإسكندرية على العصور المختلفة دائما

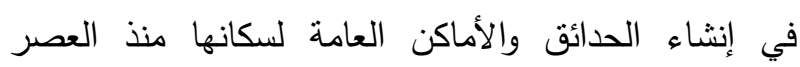

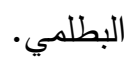

يعتبر الفقد من مساحة حديقة الثلالات كبير إلى حد ما، حيث يصل إلى نسبة 07 \%. هذا الاتجاه يثكل تهديدا خطيرا

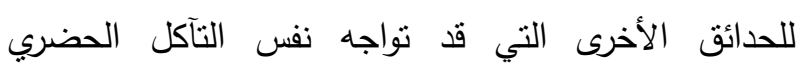

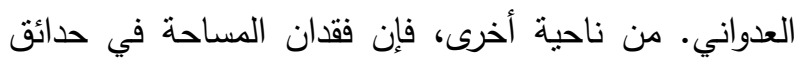
الإسكندرية المتقية موجود ولكنه غير مهدد. وكانت الخسائر

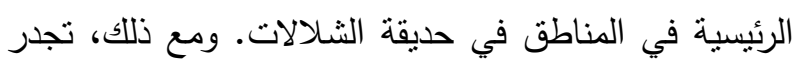
الإثارة إلى أن هذه الخسارة في المناطق الحضرية لم تؤثر

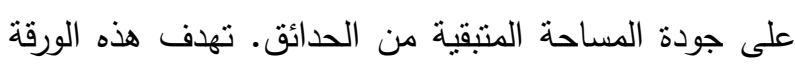
إلى تقديم صورة وصفية للحدائق التاريخية في الإسكندرية، من تصميمها الأولي إلى حالتها الحالية. 